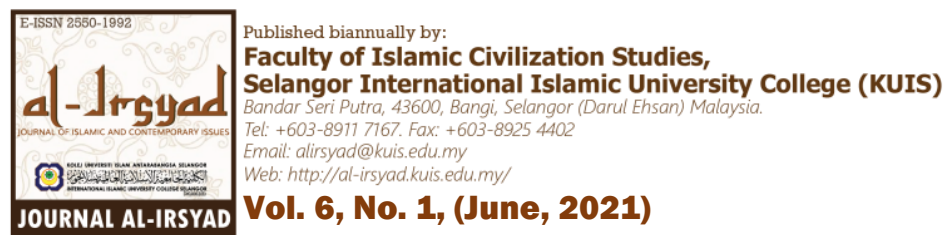

\title{
Kajian perbandingan kalangan pelajar Institusi Pengajian Tinggi terhadap simptom stres yang dialami ketika sesi pengajaran dan pembelajaran dalam talian era Covid-19
}

\section{[A comparative study among students of higher education institutions on stress symptoms during online teaching and learning in the era of Covid-19]}

\section{Zainora Daud ${ }^{1 *}$, Noorhafizah Mohd Haridi, ${ }^{2}$ Norazman Alias ${ }^{1}$ \& Anuar Hasin ${ }^{1}$}

\author{
${ }^{1}$ Faculty of Quran and Sunnah Studies, Islamic Science University of Malaysia, Negeri Sembilan, Malaysia. \\ ${ }^{2}$ Faculty of Islamic Civilization Studies, Kolej Universiti Islam Antarabangsa Selangor (KUIS), Selangor, \\ Malaysia.
}

* Corresponding Author: Dr. Zainora Daud. Faculty of Quran and Sunnah Studies, Islamic Science University of Malaysia, 71800, Bandar Baru Nilai, Negeri Sembilan, Malaysia. e-Mail: zainora@usim.edu.my. Telp.: (60) 019-2623681. ORCID iD: 0000-0002-1252-2645.

\begin{tabular}{ll}
\hline Keywords: & \multicolumn{1}{c}{ ABSTRACT } \\
\cline { 2 - 3 } Symptom, Stress, & The Covid-19 pandemic that has plagued the world to date is \\
Online & caused by the severe acute respiratory syndrome coronavirus 2 \\
(SARS-CoV-2). This has huge implications in the social, economic, \\
and education. Thus, to prevent the dispersion of this virus, the \\
Ministry of Education Malaysia (MOE), together with various other \\
parties have decided to implement online based teaching and \\
learning sessions. Hence, this new experience of online learning \\
has said to contribute stress among students in which symptoms of \\
stress are divided into physical, psychological, mental, and \\
behavioural disorders. Accordingly, this study aims to investigate \\
the comparison of stress symptoms among huffäz (Quran \\
memorizer) in the groups of Bachelor of Qira'at undergraduates. \\
These respondents are students from Universiti Sains Islam \\
Malaysia (USIM) and Kolej Universiti Islam Antarabangsa \\
Selangor (KUIS). Data collection based on questionnaire \\
instruments and descriptive analysis methods used are the \\
frequency and percentage to identify the background of students \\
and review the symptoms of stress experienced by students. The \\
findings of the study indicate that the symptoms of stress between \\
the two institutions are at different levels. The USIM respondents \\
showed that the level of their stress symptoms is at a moderate level \\
by noting that all three constructs (physical, psychological, mental) \\
are at a moderate level but the construct of stress symptoms in the \\
behavioural aspect is at a high level. Meanwhile, for the KUIS \\
respondents, the overall analysis was at a low stress level with all \\
four constructs scored low. The finding suggests that stress levels \\
are influenced by environmental conditions, circumstances, and self \\
-perceptions of the individuals. As a conclusion, good stress \\
management is an essential element for students' development in \\
line with Islamic principles.
\end{tabular}

Kata Kunci:

Simptom, Stres,
ABSTRAK

Pandemik Covid-19 yang melanda dunia sehingga hari ini berpunca 


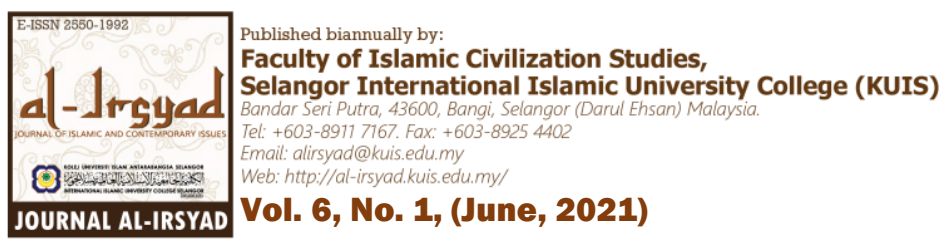

Perbandingan, Covid-19, Dalam Talian.

\begin{abstract}
daripada koronavirus sindrom pernafasan akut teruk 2 (SARS-CoV2). Ini mendatangkan suatu implikasi yang amat besar dalam aspek sosial, ekonomi, pendidikan dan sebagainya. Bagi mengelakkan penularan virus ini secara berleluasa, pihak Kementerian Pendidikan bersama-sama pelbagai pihak lain telah memutuskan sesi pengajaran dan pembelajaran dilaksanakan secara atas talian. Sehubungan itu, artikel ini bertujuan untuk membuat perbandingan simptom stres dalam kalangan para huffaz dalam bidang pengkhususan qiraat. Simptom stres terbahagi kepada fizikal, psikologikal, gangguan fikiran dan tingkah laku. Namun simptomsimptom ini memberi implikasi yang positif dan negatif dalam kehidupan individu. Implikasi positif membentuk jati diri dan motivasi pelajar ke arah kecemerlangan dalam bidang yang dipilih, akan tetapi jika mendatangkan implikasi negatif, ini akan mendorong para pelajar kepada aktiviti-aktiviti yang tidak sihat yang boleh menjejaskan kualiti pembelajaran mereka. Responden kajian terdiri daripada para pelajar di USIM dan KUIS. Pengumpulan data berdasarkan instrumen soal selidik dan kaedah analisis deskriptif yang digunakan ialah kekerapan dan peratusan bagi mengenalpasti latar belakang pelajar dan meninjau gejala stres yang dialami para pelajar. Dapatan kajian menunjukkan bahawa simptom-simptom stres antara kedua-dua institusi berada di tahap yang berbeza. Bagi responden USIM menunjukkan bahawa tahap simptom stres mereka berada di tahap sederhana dengan mencatatkan ketiga-tiga konstruk berada di tahap sederhana tetapi konstruk simptom stres dalam aspek tingkah laku berada di tahap tinggi. Manakala bagi responden KUIS mencatatkan analisis keseluruhannya berada di tahap rendah dengan hasil semua konstruk berada di tahap rendah. Ini menunjukkan bahawa tahap stres dipengaruhi dengan keadaan persekitaran, keadaan dan persepsi diri individu itu sendiri. Kesimpulannya stres memainkan peranan yang penting dalam melahirkan modal insan yang mempunyai motivasi diri yang tinggi dalam kalangan pelajar walaupun ketika menghadapi waktu getir dengan pengurusan stress mereka berdasarkan panduan Islam.
\end{abstract}

\section{Pendahuluan}

Coronavirus adalah kumpulan virus yang menyebarkan penyakit kepada mamalia, termasuk manusia dan burung. Ia ditemui pertama kali pada tahun 1960, coronavirus mendapat namanya daripada bentuknya yang seakan-akan mempunyai mahkota. Dengan sebab itu ia dinamakan corona yang membawa maksud mahkota atau crown (Al-Bakri, 2020). Menurut Pertubuhan Kesihatan Sedunia WHO bahawa Covid 19 bermaksud penyakit Korona Virus adalah nama rasmi bagi novel Korona Virus 2019. Covid 19 adalah Co singkatan bagi Corona, Vi pula perkataan virus dan D untuk penyakit iaitu Disease (Jabatan Penerangan Malaysia, 2020). Penyakit ini merupakan keluarga besar virus yang boleh menjejaskan saluran pernafasan dan menyebabkan gejala-gejala seperti selsema dan jangkitan saluran pernafasan secara akut (Perpustakaan Negara Malaysia, 2020). Kes pertama ini telah dikesan berlaku di Wuhan, China pada 31 Disember 2019 melalui sebuah pasar makanan laut (Abdullah, 2020).

Pada 25 Januari 2020, virus tersebut telah dikesan di Malaysia apabila para pelancong dari China yang tiba di Johor melalui Singapura disahkan positif dengan virus ini berpunca dari negara mereka (Sipalan, 2020) Statistik semasa pandemik Covid 19 di Malaysia menunjukkan bahawa sehingga 28 Oktober 2020 mencatatkan jumlah keseluruhan kes positif virus ini seramai 29,411 orang dengan kes kematian sebanyak 246 orang 


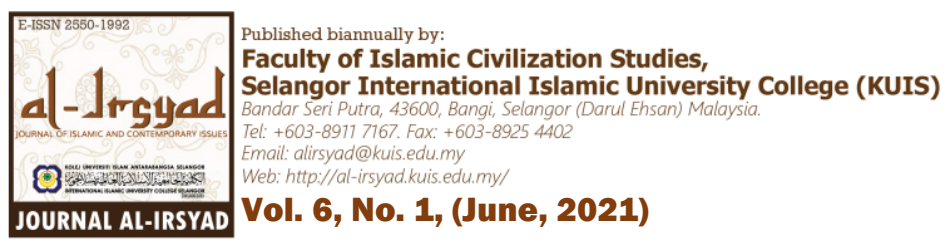

(Kementerian Kesihatan Malaysia, 2020). Wabak ini merebak begitu pantas sehingga meragut ribuan nyawa manusia di seluruh dunia. Berikutan isu ini, menyebabkan kerajaan Malaysia terpaksa memerintahkan Perintah Kawalan Pergerakan pada tempoh tertentu bagi mengekang penularan virus ini sehingga memberi implikasi yang besar kepada semua sektor termasuk sektor pendidikan (Yassin, 2020).

Pandemik Covid-19 ini telah memberi kesan terhadap pelaksanaan kaedah pengajaran dan pembelajaran secara bersemuka atau berbentuk fizikal secara langsung sebelum ini kepada pembelajaran maya sama ada secara teradun atau menggunakan web 2.0. Senario ini menyebabkan berlaku perubahan paradigma amalan yang sukar dilalui (Rathakrishnan, 2020). Bahkan perkembangan yang berlaku dalam kehidupan setiap pelajar secara langsung akan melibatkan perubahan yang berlaku terhadap proses psikologikal dan sosial mereka. Secara tidak langsung, mendatangkan risiko kepada pelajar untuk mengalami masalah tekanan mental dan sebagainya. Ini jelas dilihat berdasarkan perbandingan antara pelajar baharu dan lama (Mohamad \& Ibrahim, 2018). Malahan disokong dengan artikel Pauzi, Juhari, Amiruddin dan Mat Hassan (2020) bahawa kesan Covid 19 menyebabkan lebih banyak aktiviti pengajaran dan pembelajaran dilakukan secara luar norma, iaitu di rumah. Sudah pasti ianya cabaran baru buat pelajar dan warga pendidik.

Sehubungan itu, objektif artikel ini adalah untuk mengkaji simptom-simptom stres yang berlaku dalam kalangan para pelajar institusi pengajian tinggi di USIM dan KUIS secara perbandingan dalam bidang pengkhususan al-Quran dan al-Qiraat ketika menghadapi era Covid 19.

\section{Definisi Dan Simptom-Simptom Stres}

Definisi stres mempunyai pelbagai pengertian bergantung kepada individu atau sesuatu keadaan. Stres adalah suatu peristiwa atau pengalaman yang negatif sebagai sesuatu yang mengancam, ataupun membahayakan dan individu yang berasal dari situasi yang bersumber pada sistem biologis, psikologis dan sosial dari seseorang (Kartika, 2015). Stres memberi impak yang positif dan negatif, yang menjadi masalah sekiranya mengalami tahap stress yang melampau. Ini disokong dengan penyataan Gaol (2016), stres bukan sahaja memberi kesan negatif kepada individu, malahan juga memberi kesan positif kerana ia berpunca tahap kemampuan dan sumber stres yang dialami seseorang. Sekiranya kuantiti stres yang dialaminya sangat banyak berbanding dengan tahap kemampuan yan sangat minima, impaknya akan mendatangkan kesan negatif kepada individu tersebut, tetapi jika tahap kemampuannya seimbang atau melebihi dengan punca stres yang dialaminya, maka kesan positif akan berlaku terhadap kesihatan dan prestasi seseorang individu. Menurut Lin dan Huang (2014) sekiranya seseorang mengalami tahap stres yang tinggi akan membahayakan diri mereka sendiri termasuk pelajar. Malahan hasil kajian menunjukkan bahawa mahasiswa yang mengalami stres akan menunjukkan penurunan dalam kualiti akademik mereka, tahap kualiti kesihatan menjadi buruk, depresi dan gangguan tidur (Gaol, 2016).

Menurut Kementerian Kesihatan definisi stress ialah tindak balas fizikal, emosi dan mental seseorang terhadap sebarang perubahan atau tuntutan. Simptom stres terbahagi kepada empat iaitu fizikal, psikologikal, gangguan fikiran dan tingkah laku (Abd Kadir, 2012). Simptom-simptom stres daripada aspek fizikal ialah gementar, berpeluh, rasa seram sejuk, tangan dan kaki rasa sejuk, sakit kepala atau rasa mual, bernafas laju, kering mulut, kerap buang air kecil, kerap buang air besar, cirit birit, kurang selera makan, mudah dapat serangan penyakit seperti asma, sakit belakang badan, masalah penghadaman, sakit kepala, gatal-gatal, masalah hubungan kelamin contoh kurang minat melakukan hubungan seksual, sakit-sakit badan, cepat letih. Manakala daripada aspek psikologikal seperti kebimbangan, keliru dan kurang daya tumpuan, sukar kawalan diri, perubahan emosi seperti tekanan perasaan, kekecewaan, mewujudkan permusuhan, rasa tak berdaya, Kurang sabar dan cepat marah, lemah semangat, susah nak tidur, mudah terpengaruh mengambil bahan yang terlarang seperti dadah dan arak (Abd Kadir, 2012).

Daripada aspek gangguan fikiran seperti sukar membuat keputusan, kurang minat terhadap aktiviti harian, tidak merasa tercabar terhadap situasi yang sukar, pemikiran positif terganggu disebabkan sering berfikiran negatif, kurang memberi perhatian, hilang keyakinan diri, hilang tumpuan, penurunan kekuatan mental dalam menghadapi perasaan bingung, takut, kecewa dan cepat marah. Bahkan daripada aspek tingkah laku seperti bercakap dengan cepat dan kuat, menguap, suka gigit jari, mengetap bibir, kerap mengerakkan jari, letih, perasaan yang negatif seperti mudah tersinggung, terlalu bergantung kepada orang lain, suka memberi komen dan kritik orang lain, boleh bertindak ganas, bertindak secara tidak logik, bertindak keterlaluan dan terlalu beremosi kurang kecekapan diri seperti mudah lupa, selalu membuat kesilapan, sering terlibat kemalangan, kurang produktiviti kerja, menindakkan keupayaan diri sendiri (Abd Kadir, 2012).

Hasil kajian menunjukkan bahawa stres boleh menjadi penyebab penyakit, seperti penyakit kardiovaskuler, hipertensi, kanser, penyakit kulit, infeksi, penyakit metabolik dan hormon, serta lain sebagainya. Bahkan simptom-simptom stres yang melampau akan memberi implikasi kepada tubuh badan seperti tanda 


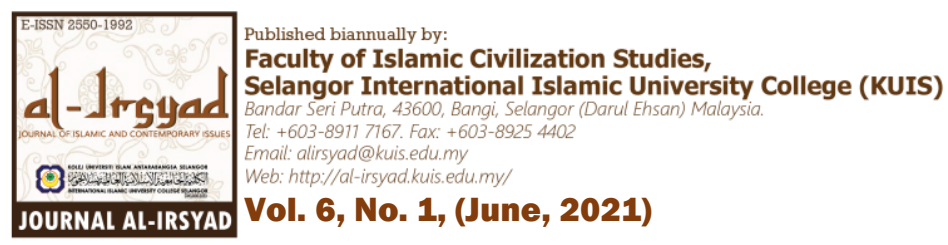

mudah lelah, sakit kepala, hilang nafsu, mudah lupa, bingung, gugup, kehilangan nafsu seksual, kelainan pencernaan dan tekanan darah tinggi (Musradinur, 2016).

\section{Universiti Sains Islam Malaysia (USIM)}

Universiti Sains Islam Malaysia (USIM) merupakan sebuah institusi pengajian tinggi awam (IPTA) yang ke-12 di Malaysia. USIM yang dahulunya dikenali sebagai KUIM telah ditubuhkan 11 Jun 1997 atas cetusan idea oleh Menteri Pendidikan ketika itu iaitu Datuk Seri Mohd Najib Tun Abdul Razak dan disokong oleh Perdana Menteri, Datuk Seri Dr. Mahathir Mohamad dengan menjadikan bahasa Arab sebagai bahasa pengantar universiti. Kini KUIM dikenali dengan nama USIM sejak berkuatkuasa pada 1 Februari 2007 (USIM, 2020).

Pada awal penubuhannya, pusat pengajian ini dijangka beroperasi pada Mei 1998 di Universiti Islam Antarabangsa (UIA) di Petaling Jaya, Selangor, apabila UIA berpindah ke kampus tetapnya di Gombak tetapi tidak berjaya direalisasikan disebabkan masalah ekonomi. Pada bulan Januari 2000, akhirnya memulakan operasinya di tingkat 5, Fakulti Pengajian Islam UKM. Kemudian telah berpindah ke IPB di Kampung Pandan, Kuala Lumpur dengan pengambilan pelajar pertama sesi 2000/2001 seramai 255 orang dalam tiga bidang pengajian iaitu Pengajian Syariah dan Kehakiman, Pengajian al-Quran dan al-Sunnah dan Pengajian Dakwah dan Pengurusan Islam. Kini USIM telah berjaya mengorak langkahnya dengan memiliki kampus tetapnya di Bandar Baru Nilai, Negeri Sembilan dan mempunyai pelajar tempatan seramai 12129 orang serta 695 pelajar antarabangsa. Sehingga kini USIM mempunyai 68 program akademik serta beberapa fakulti pengajian, antaranya Fakuti Pengajian Quran dan Sunnah, Fakulti Pengajian Bahasa Utama, Fakulti Ekonomi dan Muamalat, Fakulti Syariah dan Undang-undang serta lain-lain (USIM, 2020).

Fakulti Pengajian Quran dan Sunnah (FPQS) merupakan sebuah fakulti yang pertama ditubuhkan oleh Universiti Sains Islam Malaysia (USIM) dengan penawaran satu program iaitu program pengajian Quran dan Sunnah. Seterusnya pada sesi 2005/2006 terdapat dua program pengajian baru ditawarkan iaitu program Ijazah Sarjana Muda Pengajian Quran Dengan Multimedia (Dengan Kepujian) dan Ijazah Sarjana Muda Pengajian Sunnah Dengan Pengurusan Maklumat (Dengan Kepujian). Kini FPQS telah menawarkan pelbagai program pengajian sama ada peringkat prasiswazah dan pascasiswazah, iaitu (Fakulti Pengajian Quran dan Sunnah, 2020):

i. Ijazah Doktor Falsafah Pengajian Quran dan Sunnah

ii. Ijazah Sarjana Pengajian Quran dan Sunnah

iii. Ijazah Sarjana Muda Pengajian Quran dan Sunnah dengan Kepujian

iv. Ijazah Sarjana Muda Pengajian Quran Dengan Multimedia dengan Kepujian

v. Ijazah Sarjana Muda Pengajian Sunnah Dengan Pengurusan Maklumat

dengan Kepujian

vi. Ijazah Sarjana Muda Pengajian Quran dan Sunnah dengan Kepujian USIM di Darul Quran

vii. Ijazah Sarjana Muda Pengajian Qiraat.

Ijazah Sarjana Muda Pengajian Qiraat merupakan satu program baharu dalam Fakulti Pengajian Quran dan Sunnah, USIM yang memfokuskan bidang pengkhususan qiraat di peringkat universiti awam. Ia ditawarkan pada tahun 2019 dengan pengambilan pelajar sulongnya seramai 45 orang. Program ini dilaksanakan secara sepenuh masa dalam tempoh 4 tahun. Hasil pembelajaran program ini melahirkan para pelajar yang mampu memperoleh dan mengaplikasi pengetahuan Quran dan Sunnah dalam bidang Qiraat, menunjukkan kepakaran praktikal yang menyeluruh dalam bidang Quran dan Qiraat, berfungsi dengan berkesan secara individu atau berkumpulan dengan keupayaan untuk menjadi pemimpin, memahami dan melakukan kewajipan profesional dan kemanusiaan secara beretika, berkomunikasi secara berkesan dalam bentuk penulisan dan percakapan di antara para hafiz, ilmuan dalam bidang Quran dan Qiraat, serta menunjukkan tanggungjawab kepemimpinan yang berkesan terhadap komuniti, mengenalpasti, memformulasi dan memberikan penyelesaian yang kreatif, inovatif dan efektif kepada permasalahan dalam bidang Quran dan Qiraat, menyedari keperluan dan melibatkan diri dalam pembelajaran sepanjang hayat serta pembangunan profesional dan memotivasikan diri dan meningkatkan kemahiran keusahawanan untuk pembangunan kerjaya (Daud, 2021).

\section{Kolej Universiti Islam Antarabangsa Selangor (KUIS)}

Kolej Universiti Islam Antarabangsa Selangor (KUIS) merupakan sebuah Institusi Pengajian Tinggi Islam milik penuh Majlis Agama Islam Selangor (MAIS) yang ditubuhkan di bawah akta IPTS 1996. Penubuhannya secara 


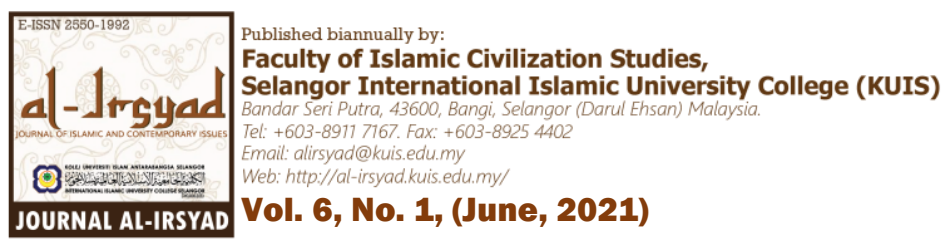

rasmi pada 15 Februari 1995 membuktikan komitmen kerajaan negeri Selangor dalam membangunkan agenda pendidikan dan kecemerlangan ilmu. Sebagai sebuah legasi pendidikan DYMM Sultan Selangor yang sentiasa dipelihara dan disantuni menjadi pemangkin tradisi ilmu dan penyatuan umat Islam di negeri Selangor, KUIS berusaha melahirkan Dai, Ulama dan Umarak (KUIS, 2020). Merujuk kertas kerja asal penubuhannya yang disediakan oleh Haji Mohd. Adanan Isman, sebagai Timbalan Pengarah Pendidikan Jabatan Agama Islam Selangor (JAIS) ketika itu seiring selepas pengumuman penubuhannya dicetuskan oleh Menteri Besar Selangor, Tan Sri Muhammad Muhd. Taib sempena majlis Konvokesyen Asas Perguruan JAIS pada 28 Januari 1995, di Dewan Jubli Perak, Shah Alam. KISDAR dikenali sebagai Kolej Islam Darul Ehsan. Pada awal pengambilannya, seramai 60 rang pelajar telah ditawarkan tempat untuk mengikuti program Diploma Pengajian Islam mulai Jun 1995 di bawah Sekolah Pengajian Islam, Kolej INPENS, sebuah institusi pengajian tinggi milik penuh Yayasan Selangor. Pada 1 Disember 1996, KISDAR mula beroperasi sepenuhnya sebagai syarikat milik penuh Majlis Agama Islam Selangor (MAIS) selepas menerima kelulusan pendaftaran daripada Jabatan Pendidikan Swasta, Kementerian Pendidikan Malaysia. KISDAR kemudian menumpang di bangunan Sekolah Agama Menengah Tengku Ampuan Jemaah (SAMTAJ) di Seksyen 11, Shah Alam untuk tempoh kira-kira empat tahun (1996-2000), sebelum berpindah ke kampus tetap seluas 104 hektar di kawasan Bangi Lama, Kajang. Pada 29 Mei 2002, Sultan Sharafuddin Idris Shah Ibni Al-Marhum Sultan Salahuddin Abdul Aziz Shah telah mengisytiharkan perasmian kampus KISDAR. Tanggal 22 Oktober 2004 bersamaan 8 Ramadan 1425H merupakan tarikh bersejarah kepada KISDAR. Pada tarikh tersebut, KISDAR secara rasmi telah dipelawa untuk dinaik taraf sebagai sebuah Kolej Universiti dalam satu majlis rasmi di Hotel J.W. Marriot, Putrajaya. Menteri Pengajian Tinggi, Dato' Dr Syafie Salleh yang mewakili Timbalan Perdana Menteri, Dato' Seri Mohd. Najib Tun Razak menganugerahkan KISDAR sijil pelawaan naik taraf sebagai Kolej Universiti.Bermula 31 Disember 2004, nama KISDAR secara rasmi diperakukan sebagai Kolej Universiti Islam Antarabangsa Selangor (KUIS) (KUIS, 2020).

Fakulti Pengajian Peradaban Islam (FPPI), pada awalnya dikenali dengan nama Sekolah Pengajian Islam (SPI),merupakan sebuah fakulti terawal (sejak tahun 1995) di KUIS yang menumpukan kepada penawaran perkhidmatan pendidikan khasnya dalam bidang Pendidikan Islam telah menawarkan pelbagai program pengajian di peringkat ijazah doktor falsafah sehingga diploma antaranya bidang pengajian qiraat (FPPI, 2020). Antara jabatan di bawah pentadbiran FPPI ialah Jabatan Tahfiz al-Quran dan al-Qiraat, KUIS telah menawarkan Diploma Tahfiz al-Quran dan al-Qiraat sejak tahun 2004 serta Ijazah Sarjana Muda al-Quran dan al-Qiraat pada tahun 2011 serta di peringkat sarjana pada tahun 2017. Jenis pengajian sepenuh masa dengan tempoh pengajian tiga tahun iaitu 6 semester (Fak. Pengajian Peradaban Islam, KUIS, 2020).

Hasil pembelajaran program ini graduan berupaya untuk mempraktikkan ilmu-ilmu yang berkaitan bidang al-Quran dan al-Qiraat dengan memantapkan diri dari aspek akademik dan sahsiah sejajar dengan perkembangan ilmu dan teknologi semasa yang memenuhi keperluan pasaran, memberikan panduan dan penyeliaan dalam latihan praktikal dan penulisan ilmiah melalui proses dan metodologi penyelidikan Islam dalam bidang al-Quran dan al-Qiraat dalam menangani permasalahan di dalam masyarakat, memenuhi keperluan masyarakat dalam bidang ilmu yang berkaitan dengan al-Quran dan al-Qiraat, menguasai bidang qiraat secara teori dan amali dari sumbernya yang asal, menjelaskan wajah-wajah qiraat yang mutawātirah yang digunakan oleh para qurra' berpandukan manāhij șaḥhh yang digunakan dalam periwayatan hadis dan pentafsiran al-Quran, mempunyai ilmu yang pelbagai khususnya dalam bidang Al-Quran dan Al-Qiraat, menguasai bidang al-Quran secara teori dan amali dan menyumbang dalam bidang keilmuan dari aspek al-quran dan al-qiraat, pembangunan sumber manusia dan keperluan guna tenaga negara (Fak. Pengajian Peradaban Islam, KUIS, 2020).

\section{Metodologi}

Kajian ini berbentuk kajian deskriptif dengan menggunakan kaedah kuantitatif. Pharmjit dan Chan (2010) menyatakan bahawa penyelidikan ini adalah sejenis penyelidikan kuantitatif yang membuat deskriptif teliti tentang fenomena pendidikan. Bahkan menurut Konting (1990) penyelidikan deskriptif adalah satu bentuk penyelidikan yang bertujuan untuk mengumpul maklumat dan menerangkan apa yang sedang berlaku.

Penyelidik memilih reka bentuk kajian deskriptif kerana dapat memberikan perihal fenomena dan keadaan simptom stres yang dialami responden yang mempunyai pelbagai aspek (Noah, 2002). Tujuan kajian deskriptif dijalankan untuk memberi penerangan yang sistematik mengenai fakta dan ciri-ciri sesuatu populasi atau bidang yang diminati secara fakta dan tepat. Metodologi yang digunakan alam kajian ini terbahagi kepada dua iaitu sample serta metod pengumpulan dan instrumen. 


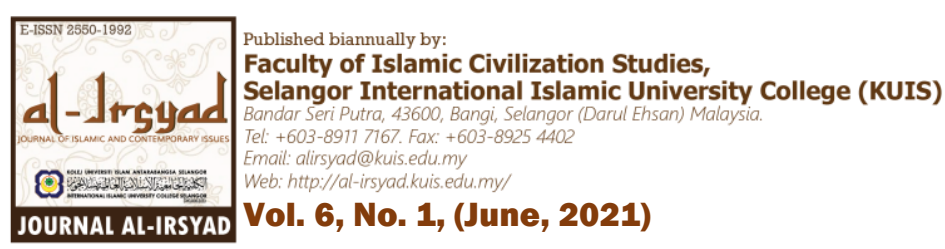

\subsection{Sample dan metod pengumpulan data}

Sampel adalah sekumpulan kecil unsur yang telah diambil daripada satu rangka persampelan. Sample juga mewakili sesuatu populasi dalam sebarang tinjauan di mana tinjauan ini bertujuan untuk membuat kesimpulan mengenai populasi berdasarkan maklumat yang terkandung dalam sample (Ayob, 1983).

Pengkaji memilih semua pelajar dalam kalangan pelajar Ijazah Sarjana Muda Pengajian Qiraat dengan Kepujian, USIM disebabkan jumlahnya sedikit, sebanyak 46 set soal selidik telah diedarkan semua pelajar tahun dua tetapi hanya 33 set soal selidik sahaja berjaya dikembalikan. Manakala bagi responden dalam kalangan Ijazah Sarjana Muda al-Quran dan al-Qiraat, KUIS hanya 27 set sahaja soal selidik yang berjaya dijawab iaitu $10 \%$ sahaja dengan menggunakan persampelan secara rawak.

Menurut teori Gay, Mills, dan Airasian (1992) bahawa minimum sample bagi sesuatu kajian adalah berdasarkan kepada bentuk kajian yang dilakukan. Bagi kajian deskriptif, minimum sample adalah $10 \%$ daripada jumlah populasi, 20\% bagi jumlah yang lebih kecil dan kajian kolerasi sekurang-kurangya $30 \%$. Pengkaji menggunakan metod pengkajian perpustakaan, metod dokumentasi serta metod tinjauan dalam pengumpulan data.

\subsection{Instrumen}

Instrumen kajian yang digunakan ialah soal selidik. Pengkaji telah mengemukakan satu set soal selidik yang terdiri lima bahagian iaitu Bahagian A merangkumi soalan berkaitan data demografi responden. Bahagian B berkaitan simptom stres daripada aspek fizikal, bahagian C simptom stres daripada aspek psikologikal, bahagian D simptom stres daripada aspek gangguan fikiran dan bahagian E simptom stres daripada aspek tingkah laku. dengan menggunakan lima skor skala likert telah ditentukan dalam kajian ini seperti dalam jadual 1 di bawah iaitu:

Jadual 1: Skala Likert Yang Digunakan Dalam Borang Soal Selidik

\begin{tabular}{ccc}
\hline Peringkat & Skala Likert \\
\hline Tidak Pernah & 1 \\
Kadang-kadang & 2 \\
Tidak Pasti & 3 \\
Kerap & 4 & 5 \\
\hline
\end{tabular}

Sumber: Diadaptasi daripada Konting, 1990; Sekaran, 2003; Daud, 2015.

Pengkaji juga menilai tahap stres yang dialami oleh pelajar berdasarkan skor min dalam jadual 2 di bawah.

Jadual 2: Ukuran Skor Min Tahap Stres

\begin{tabular}{ccc}
\hline Skor min & Interprestasi \\
\hline $3.80-5.00$ & Stres Tinggi \\
$2.40-3.79$ & Stres Sederhana \\
Stres Rendah \\
\hline Sum-2.39
\end{tabular}

Sumber: Diadaptasi daripada Wiersme,1995 dalam Mustafa, Suradin, Muhammad, Madar \& Razza. 2009.

\section{Dapatan Kajian}

Hasil dapatan kajian merangkumi dua bahagian iaitu bahagian A berkaitan demografi pelajar dan bahagian B berkaitan simptom-simptom stres yang dialami oleh respoden ditunjukkan dalam jadual-jadual di bawah. Dapatan kajian latar belakang pelajar meliputi maklumat jantina, umur, kawasan tempat tinggal, bilangan adik beradik, pekerjaan ibubapa dan kumpulan pengkelasan pendapatan. Kesemua dapatan ini boleh dilihat dalam Jadual 3 di bawah:

Jadual 3: Bahagian A Latar Belakang Pelajar

\begin{tabular}{|c|c|c|c|c|c|}
\hline \multirow[t]{2}{*}{ Item } & & \multicolumn{2}{|l|}{ USIM } & \multicolumn{2}{|l|}{ KUIS } \\
\hline & & Kekerapan & Peratusan & Kekerapan & Peratusan \\
\hline \multirow[t]{2}{*}{ Jantina } & Lelaki & 12 & $36.4 \%$ & 11 & $40.7 \%$ \\
\hline & Perempuan & 21 & $63.6 \%$ & 16 & $59.3 \%$ \\
\hline \multirow[t]{3}{*}{ Umur } & 21 & 2 & $6.0 \%$ & 2 & $7.4 \%$ \\
\hline & 22 & 27 & $82.0 \%$ & 21 & $77.8 \%$ \\
\hline & 23 & 3 & $9.0 \%$ & 3 & $11.1 \%$ \\
\hline
\end{tabular}




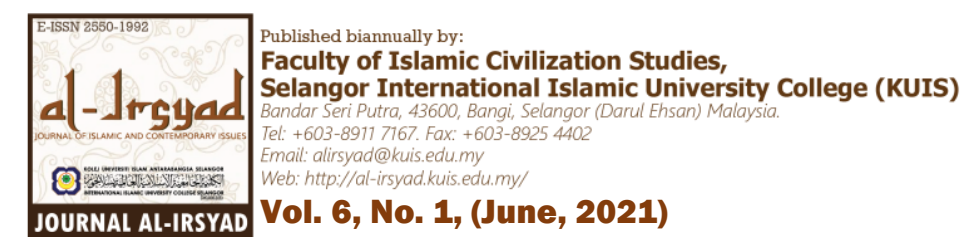

\begin{tabular}{|c|c|c|c|c|c|}
\hline & 25 & 1 & $3.0 \%$ & 1 & $3.7 \%$ \\
\hline \multirow[t]{2}{*}{ Kawasan Tempat Tinggal } & Bandar & 11 & $33.3 \%$ & 9 & $33.3 \%$ \\
\hline & Luar Bandar & 22 & $66.7 \%$ & 18 & $66.7 \%$ \\
\hline \multirow[t]{4}{*}{ Bilangan adik beradik } & $1-3$ & 6 & $18.2 \%$ & 5 & $18.5 \%$ \\
\hline & $4-6$ & 19 & $57.6 \%$ & 14 & $51.9 \%$ \\
\hline & $7-9$ & 6 & $18.2 \%$ & 5 & $18.5 \%$ \\
\hline & $10-12$ & 2 & $6.0 \%$ & 2 & $7.4 \%$ \\
\hline \multirow{2}{*}{$\begin{array}{l}\text { Adakah kedua ibubapa } \\
\text { anda bekerja? }\end{array}$} & Ya & 19 & $57.6 \%$ & 14 & $51.9 \%$ \\
\hline & Tidak & 14 & $42.4 \%$ & 13 & $48.1 \%$ \\
\hline Pengkelasan Pendapatan & T 20 & 6 & $18.2 \%$ & 6 & $22.2 \%$ \\
\hline \multirow[t]{2}{*}{ Keluarga } & M 40 & 10 & $30.3 \%$ & 9 & $33.3 \%$ \\
\hline & B40 & 17 & $51.5 \%$ & 12 & $44.5 \%$ \\
\hline
\end{tabular}

Dapatan kajian dalam jadual 3 di atas menunjukkan $70 \%$ responden dalam bidang pengkhususan program Ijazah Sarjana Muda Pengajian Qiraat dengan Kepujian, USIM yang berjaya menyerahkan soal selidik kepada pengkaji berbanding dengan 10\% sahaja dalam kalangan program Ijazah Sarjana Muda al-Quran dan alQiraat, KUIS.

Dari aspek jantina, bilangan pelajar perempuan (63.6\%) mengatasi bilangan pelajar lelaki (36.4\%) di USIM berbanding bilangan pelajar perempuan (59.3\%) juga melebihi pelajar lelaki (40.7\%) di KUIS. Dari aspek umur, di USIM majoriti berusia 22 tahun (82.0\%), 23 tahun (9.0\%), 21 tahun (6.0\%) dan 25 tahun (3.0\%). Manakala KUIS mencatatkan majoriti berusia 22 tahun (77.8\%), 23 tahun (11.1\%), 21 tahun (7.4\%) dan 25 tahun (3.7\%). Sebanyak (66.7\%) responden mendiami kawasan luar bandar berbanding (33.3\%) di kawasan bandar di USIM berbanding di KUIS pula sebanyak (66.7\%) responden mendiami kawasan luar bandar dan $(33.3 \%)$ di kawasan bandar.

Manakala dari aspek bilangan adik beradik di USIM memaparkan (50.0\%) mempunyai adik beradik seramai empat hingga enam orang, diikuti dengan peratusan yang sama iaitu (18.2\%) bagi bilangan adik beradik satu hingga tiga dan seramai tujuh hingga sembilan orang, hanya $(6.0 \%)$ sahaja yang mempunyai bilangan adik beradik antara sepuluh dan dua belas orang. KUIS mencatatkan $(51.9 \%)$ mempunyai adik beradik seramai empat hingga enam orang, diikuti dengan (22.2\%) yang mempunyai bilangan adik beradik seramai 7 hingga 9 orang, (18.5\%) seramai 1 hingga 3 orang dan (7.4\%) seramai 10 hingga 12 orang.

Dari aspek pekerjaan kedua ibubapa (USIM) pula menunjukkan 57.6\% ibubapa mempunyai kerjaya berbanding $(42.4 \%)$ tidak bekerjaya. Manakala KUIS mencatatkan $(51.9 \%)$ bagi ibubapa mempunyai kerjaya daripada $(48.1 \%)$ bagi yang tiada. Sebanyak $(51.5 \%)$ responden berada di tahap B40 dalam pengkelasan pendapatan seisi rumah, diikuti dengan (30.3\%) di M40 dan 18.2\% di T20 dalam kalangan responden USIM. (44.5\%) di tahap B40. (33.3\%) di tahap M40 dan T20 sebanyak (22.2\%) di KUIS.

\subsection{Analisis Simptom Stres Dalam Aspek Fizikal}

Hasil dapatan kajian dalam jadual 4 di bawah menunjukkan bahawa keseluruhan daripada jumlah skor min, sisihan piawian dan interpretasi tahap stres dari aspek fizikal dalam kalangan responden. Min keseluruhan item tahap stres pelajar USIM daripada aspek fizikal berada di tahap stres sederhana $(\min =2.81)$ berbanding dengan pelajar KUIS berada di tahap rendah $(\min =2.11)$.

Jadual 4: Analisis Simptom Stres Yang Dialami Dari Aspek Fizikal

\begin{tabular}{|c|c|c|c|c|c|c|}
\hline \multicolumn{4}{|c|}{ USIM } & \multicolumn{3}{|c|}{ KUIS } \\
\hline Item & Min & $\mathrm{Sp}$ & Interpretasi & Min & $\mathrm{Sp}$ & Interpretasi \\
\hline Sakit kepala & 2.27 & 1.03 & Rendah & 2.33 & 1.10 & Rendah \\
\hline Bernafas laju & 2.51 & 1.30 & Sederhana & 2.48 & 1.34 & Sederhana \\
\hline Kering mulut & 1.90 & 1.04 & Rendah & 1.81 & 1.03 & Rendah \\
\hline $\begin{array}{l}\text { Kerap buang air } \\
\text { besar/kecil }\end{array}$ & 3.75 & 2.03 & Sederhana & 1.74 & 0.90 & Rendah \\
\hline Kurang selera makan & 2.15 & 0.56 & Rendah & 2.48 & 1.22 & Sederhana \\
\hline Masalah penghadaman & 2.21 & 0.54 & Rendah & 1.59 & 0.69 & Rendah \\
\hline Gatal-gatal & 3.90 & 1.04 & Tinggi & 1.92 & 1.10 & Rendah \\
\hline Sakit belakang badan & 3.69 & 1.01 & Sederhana & 1.88 & 0.93 & Rendah \\
\hline Cepat letih & 3.18 & 0.91 & Sederhana & 2.11 & 1.28 & Rendah \\
\hline
\end{tabular}




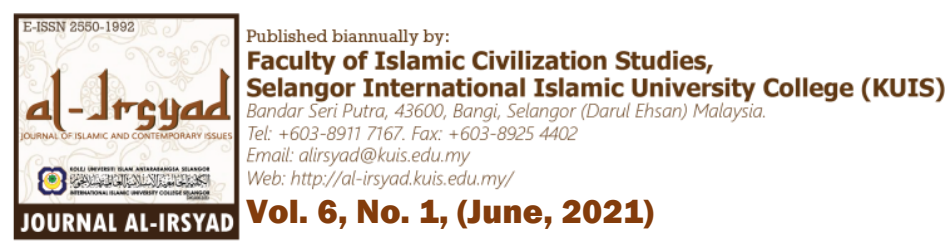

\begin{tabular}{lllllcc}
\hline Jantung berdebar-debar & 2.60 & 1.22 & Sederhana & 2.74 & 1.22 & Sederhana \\
Sukar tidur & 2.87 & 1.16 & Sederhana & 2.14 & 1.16 & Rendah \\
Jumlah & 2.81 & & Sederhana & 2.11 & Rendah \\
\hline
\end{tabular}

Jadual 4 di atas menunjukkan hasil dapatan reponden USIM bagi item mengalami kulit gatal-gatal dilihat berada di tahap tinggi ( $\mathrm{min} 3.90$ ) berbanding lapan item simptom-simptom lain berada di tahap sederhana iaitu antara min 3.75 hingga 2.51 bagi item-item seperti kerap buang air besar/kecil (min=3.75), sakit belakang badan $(\min =3.69)$, sakit badan $(\min =3.66)$, cirit birit, cepat letih, sukar tidur, jantung berdebar-debar, bernafas laju. Manakala item-item lain berada dalam tahap stres rendah antara min 2.39 hingga min 1.90 iaitu gementar, sakit kepala, masalah penghadaman, muntah atau loya, kurang selera makan dan kering mulut.

Manakala bagi responden kalangan KUIS, tiada item yang berada di tahap tinggi, cuma tiga item berada di tahap sederhana iaitu jantung berdebar-debar $(\min =2.74)$, dan $(\min =2.48)$ pada dua item iaitu bernafas laju dan kurang selera makan. Manakala item-item lain berada di tahap stress rendah iaitu antara min 2.33 hingga min 1.59 iaitu sakit kepala, sakit badan, gementar, sukar tidur, cepat letih, muntah atau loya, gatal-gatal, sakit belakang badan, cirit birit, kering mulut, kerap buang air besar/ kecil dan masalah penghadaman.

\subsection{Analisis Simptom Stres Dalam Aspek Psikologikal}

Hasil dapatan kajian dalam jadual 5 di bawah menunjukkan bahawa keseluruhan daripada jumlah skor min, sisihan piawian dan interpretasi tahap stres dari aspek psikologikal dalam kalangan responden. Min keseluruhan item tahap stres pelajar USIM daripada aspek fizikal berada di tahap stres sederhana $(\mathrm{min}=3.48)$ berbanding dengan pelajar KUIS berada di tahap rendah (min=2.14).

Jadual 5: Analisis Simptom Stres Yang Dialami Dari Aspek Psikologikal

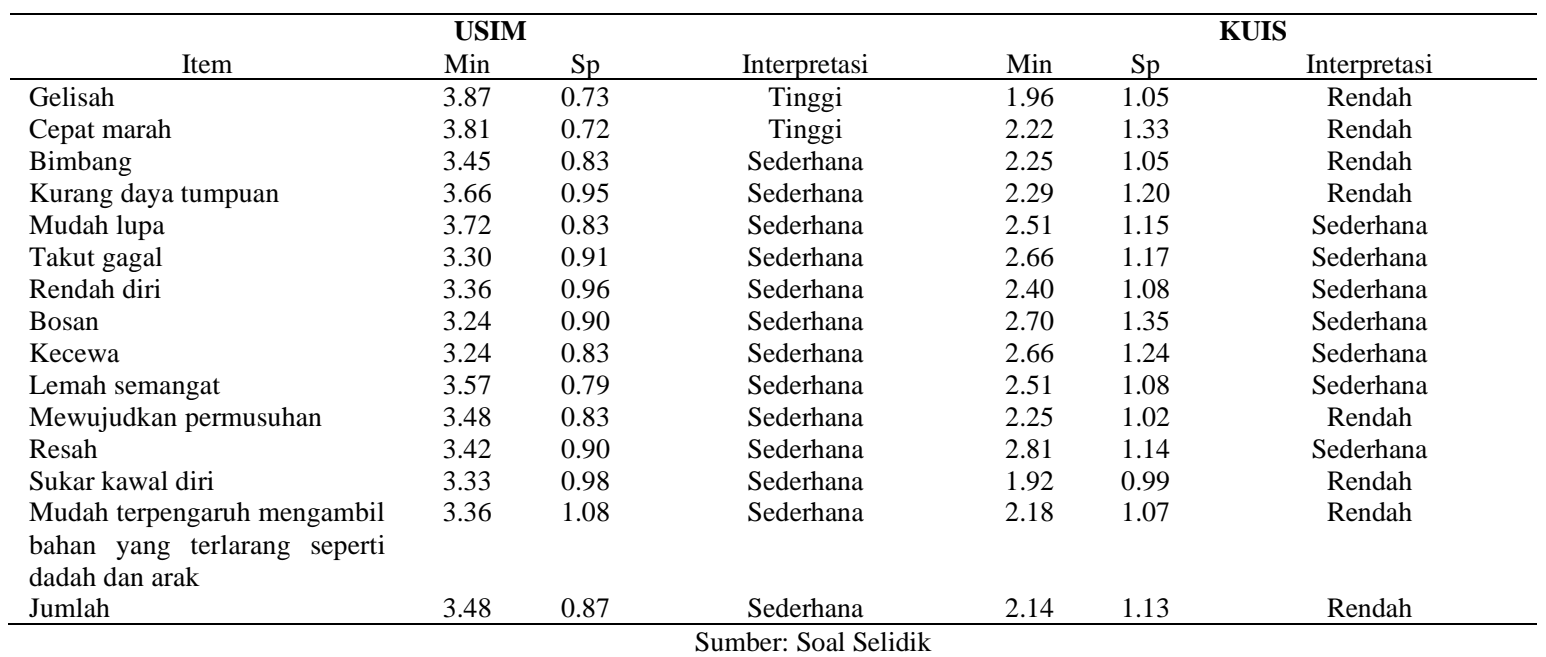

Hasil dapatan kajian dalam jadual 5 di atas menunjukkan bahawa keseluruhan daripada jumlah skor min tahap stres daripada aspek psikologikal dalam kalangan responden USIM berada di tahap stres sederhana $(\min =3.48)$ berbanding responden KUIS di tahap rendah $(\min =2.14)$. Namun bagi item gelisah dan cepat marah berada di tahap tinggi (min 3.87 dan 3.81) berbanding dua belas simptom-simptom lain yang dialami mereka berada di tahap sederhana iaitu antara min 3.72 hingga 3.24 bagi item-item mudah lupa, kurang daya tumpuan, lemah semangat, mewujudkan permusuhan, bimbang, resah, mudah terpengaruh mengambil bahan yang terlarang seperti dadah dan arak, rendah diri, sukar kawal diri, takut gagal, bosan dan kecewa. Tiada item berada di tahap stres rendah.

Ini bermakna kajian ini menunjukkan terdapat beberapa item yang berada di tahap tinggi yang perlu diberi perhatian kerana mencatatkan kesan negatif seperti item gelisah dan cepat marah. Ini disokong dengan kajian Hunt dan Eisenberg (2010) menyatakan dalam kajian-kajian mereka bahawa prevalen kecelaruan mental dalam kalangan pelajar di institut pengajian tinggi secara globalnya adalah tinggi. 


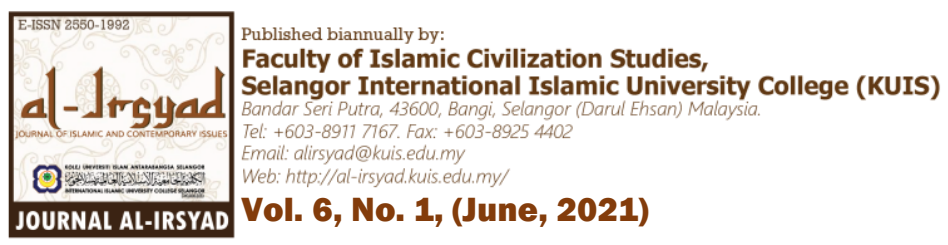

Bahkan tahap stres yang tinggi, jika tidak dikawal akan mendedahkan kebarangkalian tinggi untuk mendapat penyakit kardiovaskular seperti serangan jantung, kegagalan jantung, angin ahmar dan tekanan darah tinggi (Kementerian Kesihatan Malaysia, 2011).

Terdapat tujuh item berada di tahap sederhana iaitu antara min=2.81 hingga min=2.51 iaitu item resah, bosan, kecewa, takut gagal, mudah lupa, rendah diri dan lemah semangat. Bahkan terdapat enam item berada di tahap rendah antara min=2.29 hingga min=1.92 iaitu item kurang daya tumpuan, bimbang, mewujudkan permusuhan, cepat marah, mudah terpengaruh mengambil bahan yang terlarang seperti dadah dan arak dan sukar kawal diri.

Sehubungan dengan itu, tanda-tanda serta kesan-kesan stres yang ditunjukkan oleh individu perlu difahami dan diteliti secara baik. Ini bertujuan supaya dapat megelakkan daripada risiko stres yang semakin buruk terhadap fizikal dan psikologi (Gaol, 2016). Bahkan tiga faktor utama stres dalam kalangan pelajar institusi pengajian tinggi ialah faktor akademik, pengurusan masa dan sosial (Saad, Wan Zaimah, Zahrul \& Hussain, 2018).

\subsection{Analisis Simptom Stres Dalam Aspek Gangguan Fikiran}

Jadual 6: Analisis Simptom Stres Yang Dialami Dari Aspek Gangguan Fikiran

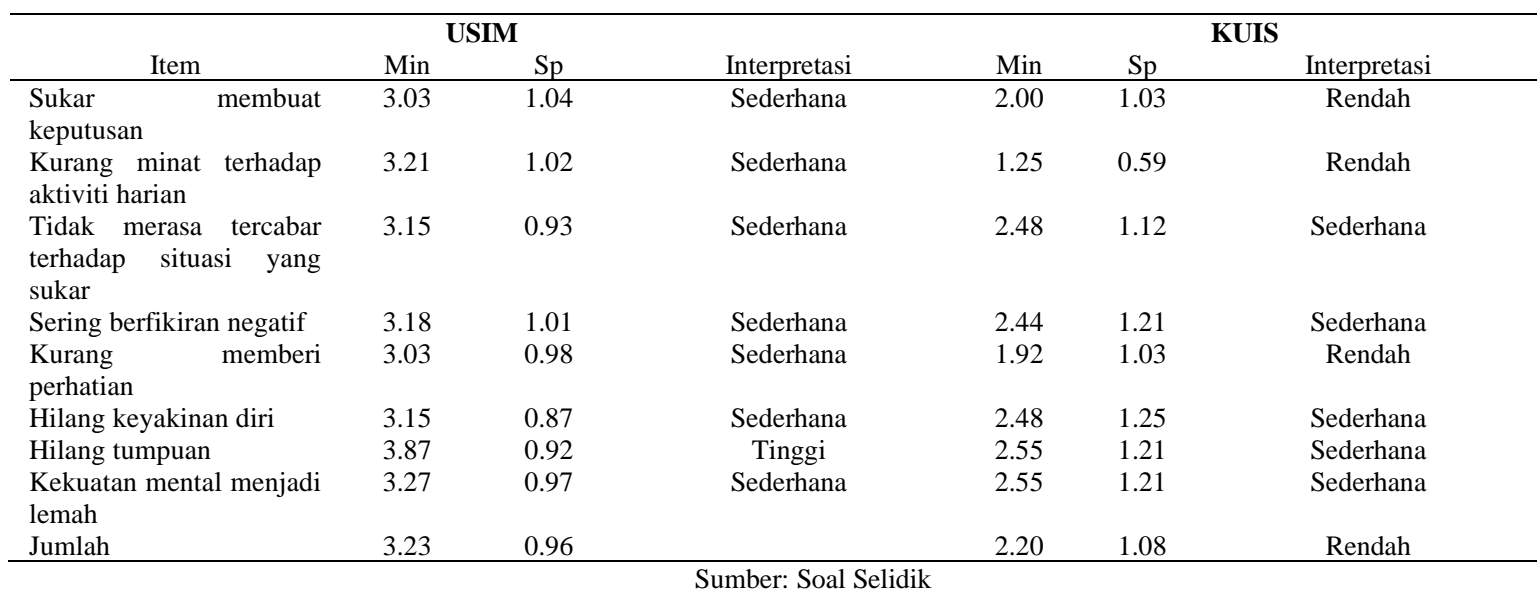

Hasil dapatan kajian dalam Jadual 6 di atas menunjukkan bahawa keseluruhan daripada jumlah skor min dalam kalangan responden USIM tahap stres dari aspek gangguan fikiran berada di tahap stres sederhana $(\min =3.23)$ berbanding dalam kalangan KUIS iaitu $(\min =2.20)$ di tahap stres rendah.

Data dalam kalangan pelajar USIM mencatatkan tiada item berada di tahap stres rendah. Namun bagi item hilang tumpuan berada di tahap tinggi (min 3.87) berbanding tujuh simptom-simptom lain yang dialami mereka berada di tahap sederhana iaitu antara (min 3.27 hingga 3.01) bagi item-item kekuatan mental menjadi lemah, kurang minat terhadap aktiviti harian, sering berfikiran negatif, tidak merasa tercabar terhadap situasi yang sukar, hilang keyakinan diri, sukar membuat keputusan dan kurang memberi perhatian.

Manakala hasil dapatan pelajar KUIS menunjukkan tiada item di tahap tinggi, bahkan terdapat lima item berada di tahap sederhana antara min=2.55 hingga min=2.44 pada item kekuatan mental menjadi lemah, hilang tumpuan, hilang keyakinan diri, tidak merasa tercabar terhadap situasi yang sukar dan sering berfikiran negatif. Tiga item berada di tahap rendah iaitu antara min=2.00 hingga min=1.25 pada item sukar membuat keputusan, kurang memberi perhatian dan kurang minat terhadap aktiviti harian. Bruffaerts et al. (2018) menjelaskan bahawa apabila masalah kesihatan mental yang tidak difahami dengan baik, akan memberi kesan kepada prestasi pembelajaran. Malahan kesihatan mental seseorang individu sangat berkaitrapat dengan tekanan psikologikal yang dihadapi serta kemampuan menanganinya. Kehidupan di universiti turut memberi risiko kepada pelajar untuk mengalami masalah tekanan mental dan sebagainya kerana cita-cita dan harapan mencapai kejayaan di peringkat pengajian tinggi (Mohammad \& Ibrahim, 2018).

Stres ialah keadaan individu yang tidak stabil dalam aspek fizikal dan mental yang berkaitrapat dengan gaya hidup kita (Ismaal, 2017). Malahan tahap stres juga berpunca kepada beberapa faktor-faktor seperti personaliti, pemikiran negatif, perasaan negatif, persekitaran sosial, sosial dan sebagainya (Kementerian Kesihatan Malaysia, 2011). Menurut Saad et al. (2018) bahawa stres merupakan satu lumrah yang terpaksa dilalui dalam kehidupan dalam dunia pembelajaran. Namun, stres yang dialami dapat membangkitkan semangat 


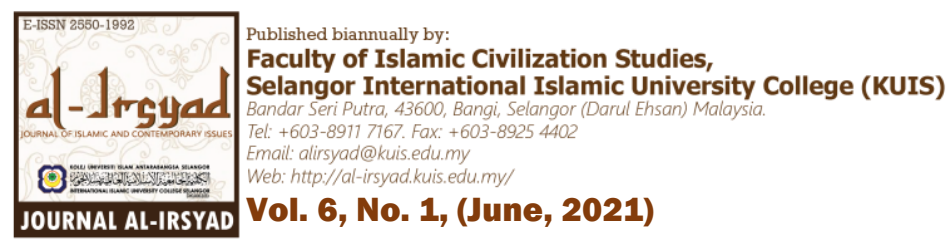

juang yang tinggi dalam diri pelajar bagi mencapai matlamat yang telah ditetapkan jika ia diuruskan dengan baik.

\subsection{Analisis Simptom Stres Dalam Aspek Tingkah Laku}

Hasil dapatan kajian dalam jadual 7 di atas menunjukkan bahawa keseluruhan daripada jumlah skor min tahap stres dalam kalangan responden USIM daripada aspek gangguan fikiran berada di tahap stres sederhana $(\min =3.77)$ berbanding $(\min =2.09)$ di tahap rendah dalam kalangan responden KUIS.

Jadual 7: Analisis Simptom Stres Yang Dialami Dari Aspek Tingkah Laku

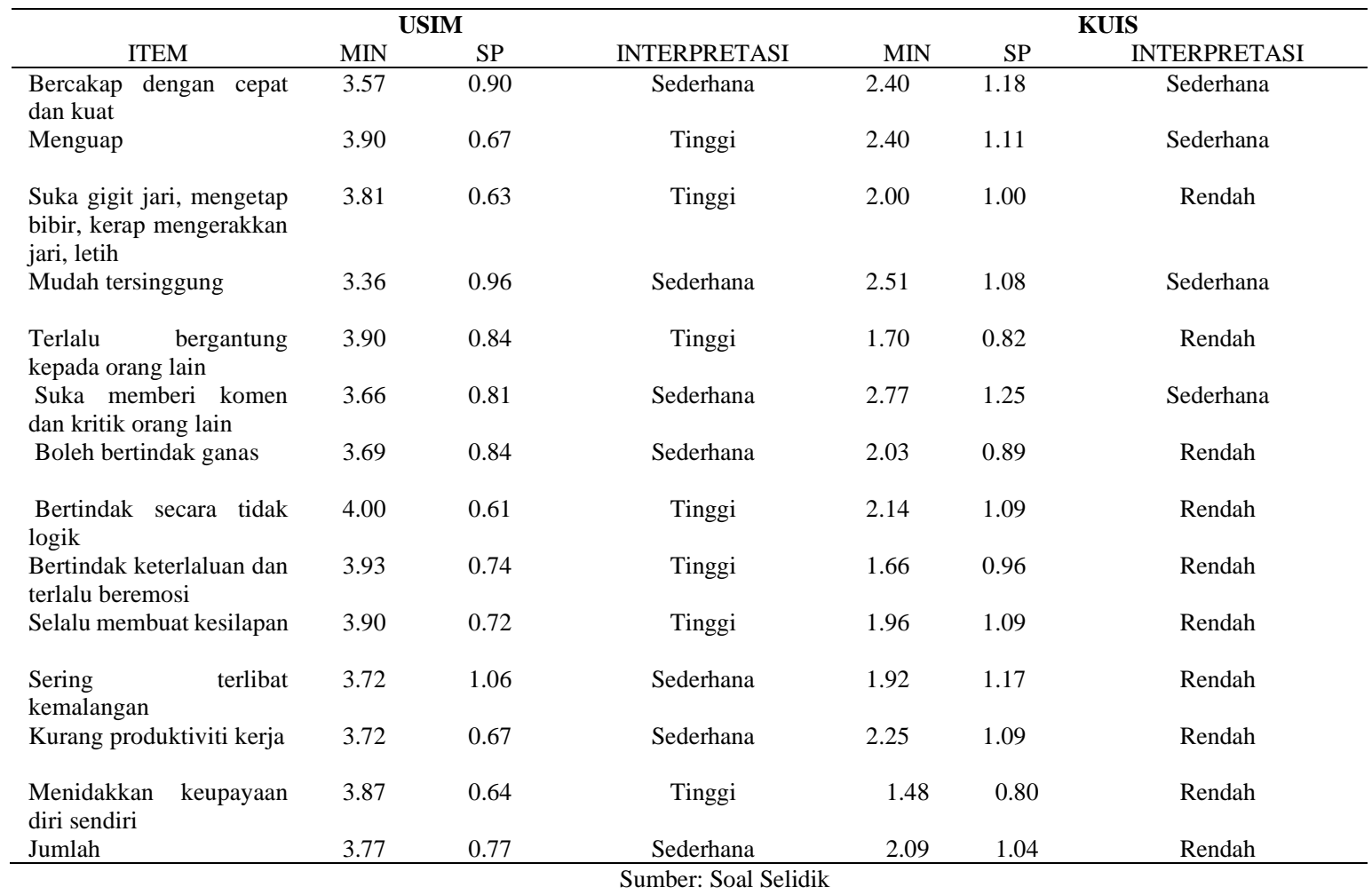

Hasil dapatan dalam kalangan responden USIM, tiada item berada di tahap stres rendah. Namun terdapat tujuh item berada di tahap stres yang tinggi iaitu antara min 4.00 hingga 3.81 , item bertindak secara tidak logik merupakan simptom stres yang tertinggi diikut dengan item bertindak keterlaluan dan terlalu beremosi, selalu membuat kesilapan, terlalu bergantung kepada orang lain, menguap, menidakkan keupayaan diri sendiri dan suka gigit jari, mengetap bibir, kerap mengerakkan jari, letih. Ini disokong dengan artikel Ismaal (2017) bahawa antara masalah kesihatan yang menyebabkan stres ialah insomnia dan susah tidur.

Manakala enam item lagi berada di tahap sederhana iaitu antara min 3.72 hingga 3.36 bagi item-item sering terlibat kemalangan, kurang produktiviti kerja, boleh bertindak ganas, suka memberi komen dan kritik orang lain, bercakap dengan cepat dan kuat dan mudah tersinggung.

Daripada aspek responden KUIS, tiada item berada di tahap tinggi, hanya empat item mencatatkan tahap stres sederhana iaitu antara $(\min =2.77)$ hingga $(\min =2.40)$ iaitu suka memberi komen dan kritik orang lain, mudah tersinggung, bercakap dengan cepat dan kuat serta menguap. Baki kesemua item berada di tahap rendah iaitu antara $(\min =2.25)$ hingga $(\min =1.48)$ iaitu kurang produktiviti kerja, bertindak secara tidak logik, boleh bertindak ganas, suka gigit jari, mengetap bibir, kerap mengerakkan jari, letih, selalu membuat kesilapan, sering terlibat kemalangan, terlalu bergantung kepada orang lain, bertindak keterlaluan dan terlalu beremosi serta menidakkan keupayaan diri sendiri. Hasil dapatan ini menunjukkan bahawa tahap stres dalam aspek tingkah laku masih boleh dikawal, data ini disokong dengan punca-punca penyebab kesihatan mental berkaitrapat dengan tahap pendidikan. Ini dibuktikan bahawa masalah mental adalah lebih tinggi di kalangan mereka yang tiada pendidikan atau berpendidikan rendah (15-16\%) (Abdul Ghani, 2013). 


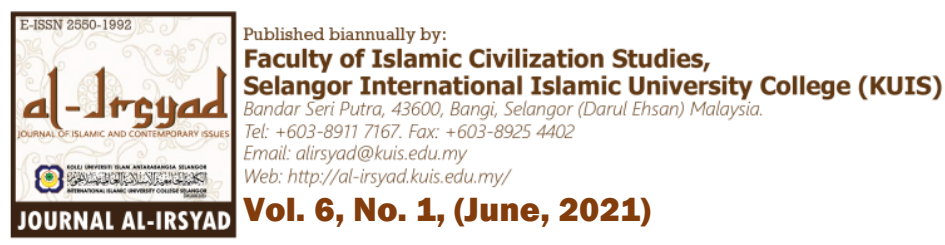

\section{Perbincangan}

Dapatan kajian berkaitan latar belakang pelajar kedua-dua institusi mencatatkan jumlah pelajar perempuan lebih ramai daripada pelajar lelaki dan majoriti pelajar berusia 22 tahun. Usia ini disokong dengan antara syarat-syarat kemasukan pelajar bagi program ini adalah pelajar lepasan Diploma Tahfiz al-Quran atau mempunyai sijil hafazan 30 juzuk sebagai pengkhususan dalam bidang qiraat (USIM, 2020).

Bahkan, hampir sebahagian besar daripada mereka tinggal di kawasan luar bandar. Kebanyakan mereka mempunyai bilangan adik beradik antara empat hingga enam orang. Sebahagian besar ibu bapa responden bekerjaya. Malahan majoriti dalam kalangan mereka berada di tahap B40 dalam pendapatan seisi rumah. Ini boleh menyumbang faktor -faktor permasalahan stres. Sebagaimana hasil kajian Arshat, Pai dan Ismail (2018) mencatatkan bahawa tiga tema tekanan telah dikenalpasti berlaku dalam kalangan keluarga B40 iaitu tekanan ekonomi, tekanan emosi dan tekanan keibubapaan.

Berdasarkan analisis keseluruhan yang telah dikemukakan oleh responden dalam jadual 8 di bawah menunjukkan simptom-simptom stres yang dihadapi para pelajar dua institusi berada di tahap yang berbeza. Bagi responden USIM menunjukkan tahap simptom stres mereka berada di tahap sederhana dengan mencatatkan ketiga-tiga konstruk berada di tahap sederhana tetapi konstruk simptom stres dalam aspek tingkah laku berada di tahap tinggi dengan item-item bertindak secara tidak logik, bertindak keterlaluan dan terlalu beremosi, selalu membuat kesilapan, terlalu bergantung kepada orang lain, menguap, menidakkan keupayaan diri sendiri dan suka gigit jari, mengetap bibir, kerap mengerakkan jari, letih berada di tahap tinggi.

Manakala bagi responden KUIS mencatatkan analisis keseluruhannya berada di tahap rendah dengan hasil semua konstruk berada di tahap rendah, namun jika dilihat perbandingan kepada item-item yang berada di tahap tinggi dalam kalangan responden USIM, hasil dapatan para pelajar KUIS menunjukkan hanya satu item yang sama tetapi berada di tahap sederhana iaitu menguap ditambah dengan tiga item lain yang mempunyai tahap yang sama dalam kalangan pelajar USIM dan KUIS iaitu suka memberi komen dan kritik orang lain, mudah tersinggung serta bercakap dengan cepat dan kuat.

Justeru itu kestabilan emosi manusia adalah berbeza, oleh itu setiap individu perlu mengenali, memahami emosi mereka untuk menyeimbangkannya dan mengawal diri supaya mampu berfikir dan bertindak tanpa pengaruh emosi (Ahmad Ibrahim, Wan Razali, \& Osman, 2011).

Kesimpulannya, mahasiswa di institusi pengajian tinggi, mereka mempunyai semangat dan inisiatif untuk mempertingkatkan ilmu dalam agama dan mempunyai peribadi yang mendekatkan diri dengan Islam. Di samping itu, mereka juga mempunyai rasa tanggungjawab kepada persekitaran dan juga mempunyai semangat persaudaraan sesama insan dengan mengekalkan rasa hormat dalam diri. Mahasiswa juga menyedari kepentingan untuk serius dalam mencapai satu-satu matlamat yang ditetapkan. Umumnya, pengamalan akhlak dalam kalangan majoriti mahasiswa berada pada tahap yang baik hanya berbeza dari segi kekerapan mereka melakukannya. Tidak mudah untuk istiqamah dalam berakhlak mulia sama ada secara bersendirian mahupun di tengah ramai (Ismail, Bakar, Abd. Majid, \& Kasan, 2019).

Jadual 8: Analisis Tahap Stres Terhadap Keseluruhan Simptom

\begin{tabular}{ccc}
\hline Kategori Simptom Stres & USIM & Skor Min \\
& KUIS \\
\hline Fizikal & 2.81 & 2.11 \\
Psikologikal & 3.48 & 2.14 \\
Gangguan fikiran & 3.23 & 2.20 \\
Tingkah laku & 3.77 & 2.09 \\
Jumlah & 3.32 & 2.13 \\
\hline
\end{tabular}

Walaupun terdapat perbezaan yang agak ketara antara dua institusi, tetapi stres yang berada di tahap rendah juga perlu diberi perhatian kerana stres merupakan tindak balas atau tingkah laku terhadap sesuatu perkara yang akan mendatangkan impak dan kesan dalam pembelajaran serta tahap pencapaian pelajar. Bahkan stres yang sederhana memberi impak yang amat positif dalam kehidupan kerana ia berkaitrapat dengan dorongan untuk peningkatan. Yaacob, Ibrahim, Rasdan dan Majdi (2009) menyatakan bahawa stres telah dikenal pasti sebagai punca kepada hampir semua masalah yang wujud dan kecelaruan psikologi. Stres sering dikaitkan dengan pembelajaran. Stres yang sederhana boleh menjadi suatu bentuk dorongan yang kuat.

Apabila seseorang mengalami stres rendah, hasil kerjanya juga rendah kerana kurangnya motivasi dan tumpuan kepada kerja. Dan begitu sebaliknya apabila stres berada di peringkat tinggi, seseorang itu akan mengalami tekanan dan menunjukkan tanda-tanda stress. Manakala stres di peringkat sederhana adalah yang 


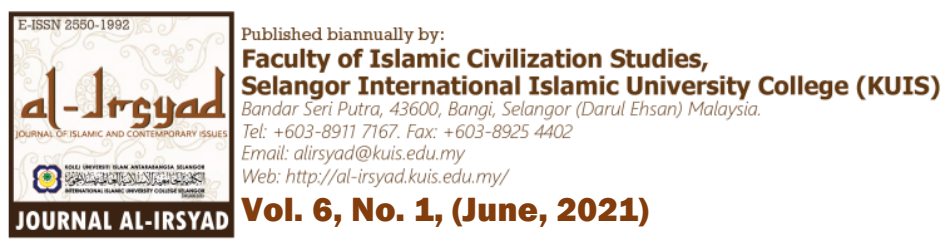

paling baik kerana ia akan meningkatkan motivasi dan perkembangan hidup seseorang itu (Abd Kadir, 2012). Namun stres merupakan fenomena yang kompleks mempengaruhi seseorang, bukan sahaja fizikal badannya tetapi melibatkan faktor yang segelintirnya mungkin belum dikenal pasti oleh para cendekiawan dan penyelidik (Sipon, Othman \& Abdul Rahman, 2013).

\section{Kesimpulan}

Hasil analisis kajian deskriptif ini menunjukkan bahawa simptom-simptom stres kedua-dua institusi berada di tahap yang berbeza. Responden daripada Ijazah Sarjana Muda Pengajian Qiraat USIM mencatatkan tahap stress mereka berada di tahap sederhana iaitu tahap yang normal dan masih berada dalam kawalan. Namun perlu diberi perhatian terhadap item-item yang berada di tahap tinggi. Manakala bagi responden daripada Ijazah Sarjana Muda al-Quran dan al-Qiraat, KUIS mencatatkan tahap yang rendah iaitu simptom-simptom stres mereka berada di tahap yang sedikit membimbangkan kerana ia memberi kesan dengan hasil pembelajaran. Namun hasil kajian daripada kedua-dua institusi menunjukkan para responden memiliki pergantungan yang kuat dengan Allah SWT dan imej mereka sebagai Hamalah (Penanggung) al-Quran terlakar jelas dengan keperibadian yang tinggi kerana mereka berjaya mengawal diri serta perasaan mereka supaya tidak terjerumus dengan tahap stres yang melampau.

\section{Rujukan}

Abd Kadir, M. N. (2012). Pengurusan stres pelajar. Dicapai daripada http://www.kmj.matrik.edu.my/mengenai-kami/jabatan- pengurusan-pelajar/.

Abdul Ghani, F. (2013) Memahami masalah kesihatan mental. Dicapai daripada http://www.myhealth.gov.my/memahami-masalah-kesihatan-mental.

Abdullah, N. (2020). Kesiapsiagaan dan respons KKM dalam menghadapi potensi penularan Novel Coronavirus, Wuhan, China. Kementerian Kesihatan Malaysia: Putrajaya. Dicapai daripada https://kpkesihatan.com/2020/01/16/kenyataan-akhbar-kpk-16-januari-2020-kesiapsiagaan-danrespons-kkm-dalam-menghadapi-potensi-penularan-novel-coronavirus-wuhan-china/.

Ahmad Ibrahim, M. A., Wan Razali, W. M. F. A., \& Osman, H. (2011). Kaunseling dalam Islam. Nilai: USIM.

Al-Bakri, Z. M. (2020). Soal jawab Fiqh Covid 19 edisi kemas kini. Putrajaya: Pejabat Menteri Agama, Jabatan Perdana Menteri.

Arshat, Z., Pai, F. S., \& Ismail, Z. (2018). Keluarga B40 tekanan dan kekuatan B40. Dicapai daripada https://www.researchgate.net/publication/Keluarga_B40_Tekanan_dan_Kekuatan_B40_Family_Stress_a nd_Strength.

Ayob, A. M. (1983). Kaedah penyelidikan sosioekonomi: suatu pengenalan. Kuala Lumpur: Dewan Bahasa dan Pustaka.

Bruffaerts, R., Mortier, P., Kiekens, G., Auerbach, R. P., Cuijpers, P., Demyttenaere, K., \& Kessler, R. C. (2018). Mental health problems in college freshmen: Prevalence and academic functioning. Journal of Affective Disorders, 225(1), 97-103. https://doi.org/10.1016/j.jad.2017.07.044.

Daud, Z. (2015). Penilaian pelaksanaan kurikulum Qiraat di Darul Quran dan Ma'ahad Tahfiz al-Quran di Malaysia (Tesis PhD tidak diterbitkan), Universiti Malaya, Malaysia.

Daud, Z. (2021). Temubual bersama Ketua Program Pengajian Qiraat, USIM pada 1 Januari 2021.

Fakulti Pengajian Peradaban Islam, (FPPI) KUIS. (2020). Program pengajian. Dicapai daripada www.fppi. kuis.edu. my,/online app2. kuis. edu.my: 8080/ online app /program/MT08.pdf.

Fakulti Pengajian Quran dan Sunnah. (2020). Penubuhan Fakulti Pengajian Quran dan Sunnah. Dicapai daripada www.fpqs.usim.edu.my.

Gaol, N. T. L. (2016). Teori stres: stimulus, respons, dan transaksional. Buletin Psikologi, 24(1), 1-11. Dicapai daripada https://jurnal.ugm.ac.id/buletinpsikologi/article/view/11224.

Gay, L. R., Mills, G. E. \& Airasian, P. (1992). Educational research: competencies for analysis and application. New York, NY: Macmillan Publishing Company.

Hunt, J. \& Eisenberg, D. (2010). Mental health problems and help seeking behavoir among college students. Journal of Adolescent Health, (46). https://doi.org/10.1016/j.jadohealth.2009.08.008.

Ismaal, I. H. (2017). Stres dan kesihatan. Kuala Lumpur: Pusat Kesihatan Universiti, UTM. Dicapai daripada https://kl.utm.my/pendaftar/files/2017/10/Stress-dan-kesihatan-Dr.-Izzat-Hazmir-bin-Ismaal.pdf.

Ismail, N., Bakar, N. H., Abd. Majid, M., \& Kasan, H. (2019). Pengamalan hidup beragama dalam kalangan mahasiswa Institut Pengajian Tinggi Islam di Malaysia. Al-Irsyad: Journal of Islamic And 


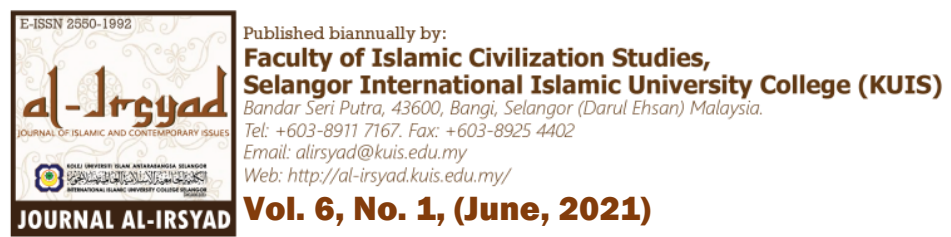

irsyad.kuis.edu.my/index.php/alirsyad/article/view/57/43.

Jabatan Penerangan Malaysia. (2020). Covid-19' nama rasmi bagi Novel Coronavirus 2019 - WHO. Dicapai pada Disember 2, 2020 daripada https://www.penerangan.gov.my/japenv2/index.php/2020 /02/12 /covid-19-nama-rasmi-bagi-novel-coronavirus-2019-who/.

Kartika, C. D. (2015). Hubungan antara kecerdasan emosi dengan stres akademik mahasiswa Fakultas Psikologi Universitas Muhammadiyah Surakarta. (Tesis Sarjana, tidak diterbitkan). Fakultas Psikologi Universitas Muhammadiyah Surakarta, Indonesia.

Kementerian Kesihatan Malaysia. (2011). Panduan menangani stres. Dicapai pada September 21, 2020 daripada https://www.moh.gov.my/moh/resources/Penerbitan/Rujukan /NCD/Kesihatan\%20Mental/6_Panduan_Menangani_Stres.pdf).

Kementerian Kesihatan Malaysia. (2020). Statistik Covid 19. Dicapai pada September 20, 2020 daripada http://covid-19.moh.gov.my/terkini.

Konting, M. M. (1990). Kaedah penyelidikan. Kuala Lumpur: Dewan Bahasa dan Pustaka.

KUIS. (2020). Latarbelakang KUIS. Dicapai daripada http://www.kuis.edu.my/latar-belakang.

Mohamad, M. S., \& Ibrahim, R. (2018). Perbezaan gender tekanan psikologikal dan kesihatan mental dalam kalangan pelajar prasiswazah. Jurnal Personalia Pelajar, 21(1), 55-66. Retrieved from http://journalarticle.ukm.my/15985/1/Artikel-7 Suhaimi_final.pdf.

Musradinur. (2016). Stres dan cara mengatasinya. Jurnal Edukasi, 2(2), 183-200. Retrieved from https://jurnal.ar-raniry.ac.id/index.php/cobaBK/article/view/815/632.

Mustafa, M. Z., Suradin, A., Muhammad, S. S., Madar, A. R., \& Razza, A. R. (2009). Kajian stres dalam kalangan pelajar wanita program Sarjana Muda Kejuruteraan di Universiti Tun Hussein Onn Malaysia (UTHM). Dicapai daripada https://core.ac.uk/display/12005662.

Noah, S M. (2002). Reka bentuk penyelidikan falsafah, teori dan praktis. Serdang: Universiti Putra Malaysia.

Pauzi, M. F., Juhari, S. N., Amiruddin, S., \& Mat Hassan, N. (2020). Covid-19: Pengajaran dan pembelajaran sewaktu krisis pandemik. Jurnal Refleksi Kepemimpinan, III. 96-105. Retrieved from http://myjms.mohe.gov.my/index.php/jrk/article/view/9892.

Perpustakaan Negara Malaysia. (2020). Maklumat Covid 19. Dicapai pada September 20, 2020 daripada https:// www.pnm. gov.my/pnm/ resources/ pdf /Aktiviti /minipakejancovid.pdf).

Pharmjit, S., \& Chan, Y. F. (2010). Panduan komprehensif penulisan cadangan penyelidikan. Shah Alam: UPENA, UITM.

Rathakrishnan, M. (2020). COVID-19 ubah pengajaran dan pembelajaran dari rumah. Dicapai daripada https://www.bharian.com.my/rencana/komentar/2020/07/710464/covid-19-ubah-pengajaran-danpembelajaran -dari-rumah.

Saad, S. S., Wan Zaimah, D., Zahrul, A., \& Hussain, O. (2018). Pengurusan stres dalam kalangan pelajar universiti. $\quad$ Retrieved from https://www.researchgate.net/publication/322222527_PENGURUSAN_STRES_DALAM_KALANGA N_PELAJAR_UNIVERSITI.

Sekaran, U. (2003). Research methods for bussiness a skill-building approach. USA: John Wiley \& Sons.

Sipalan, J. (2020). Malaysia confirms first cases of coronavirus infection. Reuters. Dicapai daripada reuters.com/article/china-health-malaysia-idUSL4N29U03A.

Sipon, S., Othman, K., \& Abdul Rahman, A. (2013). Stres, punca, teori dan pengurusan efektif. Nilai: Universiti Sains Islam Malaysia.

USIM. (2020). Bahagian akademik, USIM. Dicapai daripada www.edocs.usim.edu.my.

Yaacob, A. R., Ibrahim, R. A., Rashdan, R., \& Majdi @ Abd Hadi, I. (2009). Punca stress di kalangan pelajar Politeknik Tuanku Syed Sirajuddin. Dicapai daripada www. academia. edu /7105868/Punca _ STRESS_di kalangan_pelajar.

Yassin, M. (2020). Perutusan khas YAB Perdana Menteri mengenai Covid-19. Dicapai pada Mac 16, 2021 daripada https:// www. pmo.gov.my/ms/2020/03/perutusan-khas-yab-perdana-menteri-mengenai-covid19-16-mac-2020-2/. 